\title{
Are routine preoperative medical tests needed with cataract surgery?
}

\author{
Rodrigo P. C. Lira, ${ }^{1}$ Maurício A. Nascimento, ${ }^{1}$ Djalma C. Moreira-Filho, ${ }^{1}$ \\ Newton Kara-José, ${ }^{1}$ and Carlos E. L. Arieta ${ }^{1}$
}

ABSTRACT Objective. The objective of this study was to investigate whether routine medical testing before cataract surgery reduces the rate of complications during the perioperative period in adults. Methods. The study was carried out in an academic medical center in Brazil, between 10 February 2000 and 10 January 2001. The scheduled cataract operations were randomly assigned to one of two groups: 1) to be preceded by routine testing (the "routine-testing group") or 2) not to be preceded by routine medical testing (the "selective-testing group"). If the patient was assigned to the selective-testing group, it was requested that no preoperative testing be performed unless the patient presented with a new or worsening medical problem that would warrant medical evaluation with testing. In the case of patients assigned to the routinetesting group, three tests were requested: a 12-lead electrocardiogram, a complete blood count, and measurements of serum glucose.

Results. The sample of 1025 patients scheduled to undergo cataract surgery was comprised of 512 assigned to the routine-testing group and of 513 assigned to the selective-testing group. The two groups had similar proportions of operations canceled and not subsequently rescheduled, $2 \%$ in each group. The cumulative rate of medical events was similar in the two groups, $9.6 \%$ in the routine-testing group and $9.7 \%$ in the selective-testing group $(\mathrm{P}=0.923)$. The types of medical events were also similar in both groups.

Discussion. The results of this study suggest that routine medical testing before cataract surgery does not reduce the rate of complications during the perioperative period. The results also suggest it would be more efficient not to request routine preoperative tests unless indicated by patient history or physical examination.

Key words Cataracts, utilization of health services, elderly, diagnostic tests, preoperative care.

Around the world, cataracts are the most prevalent cause of visual loss, and an increase in their number can be expected over the next several decades as the median age of the population rises (1-3). The only effective treat-

\footnotetext{
State University of Campinas - UNICAMP, Department of Ophthalmology, Campinas, São Paulo, Brazil. Send correspondence to: Rodrigo Pessoa Cavalcanti Lira, Rua Visconde de Itaparica n. 174, apt. 203 B, 50710-090 - Recife - PE - Brazil; telephone: 5581 3228.0510; fax: 5581 3231.5532; e-mail: rpclira@uol.com.br
}

ment for cataracts is surgery, but cataract surgery has fortunately become one of the safest, most successful, and most frequently performed outpatient surgeries (4-6).

Previous studies in developed countries have demonstrated that physicians usually request routine tests regardless of the patient's preoperative status, but there is a lack of information relative to developing countries $(7,8)$. Some of the reasons for requesting nonselective tests are that cataract patients tend to be elderly and to have serious coexisting illnesses; another common argument is that the individual cost of tests is low $(1,9,10)$.

That accepted dogma regarding the validity of preoperative medical testing is now being questioned, and what was considered optimum preoperative care is being reassessed worldwide from the perspective of medical necessity and costs $(11,12)$. The need for routine laboratory tests before cataract surgery and other types of elective 
surgery has been questioned in several studies $(8,9,11)$. There is evidence that selective requests for preoperative tests would be a more rational approach $(7,8,13)$. Arterial hypertension, bronchospasm, and arrhythmia account for more than $90 \%$ of intraoperative medical events in cataract surgery, and routine tests do not appear to predict them $(9,14)$.

Seventy percent of laboratory tests ordered preoperatively in general surgery are not required, based on the patient history and the results of physical examination $(15,16)$. More than 250000 cataract surgeries are performed each year in Brazil (17). Given the number of those operations, there is a significant potential economic impact to rationalizing preoperative testing for low-income populations in developing countries and for public health services that are under functional and economic strain. And while true now, that concern will grow in the future as the populations of developing countries continue to age.

The aim of this prospective randomized clinical trial was to investigate whether routine medical testing before cataract surgery reduced the rate of complications during the perioperative period.

\section{METHODS}

\section{Patients and medical procedures}

The study was carried out in an academic medical center in Brazil. The medical center's human-subjects committee approved the study protocol. All the surgeries were performed at that same academic medical center, at the State University of Campinas, Brazil.

Patients scheduled to undergo cataract surgery were recruited between 10 February 2000 and 10 January 2001. Patients were excluded from the study if they were less than 40 years old, were undergoing surgery on the second eye, were to receive general anesthesia, or had had a myocardial infarction within the preceding 3 months. All patients provided written informed consent before enrollment in the study.

For the patients who agreed to participate in the study, the scheduled cataract operation was randomly assigned to one of two groups: 1) to be preceded by routine testing (the "routine-testing group") or 2) not to be preceded by routine medical testing (the "selective-testing group"). All patients had a preoperative medical assessment performed by a physician. If the patient was assigned to the selectivetesting group, it was requested that no preoperative testing be performed unless the patient presented with a new or worsening medical problem that would warrant medical evaluation with testing, even if surgery were not planned. For patients assigned to the routine-testing group it was requested that three tests be done: a 12-lead electrocardiogram, a complete blood count, and measurements of serum glucose.

\section{Data collection and outcomes}

Preoperative data were collected by means of a medical-history form, completed by the physician at the time of preoperative medical examination. Intraoperative medical events and treatments were recorded on a standardized form by the ophthalmologist or a member of the nursing staff.
The definitions of adverse medical events used in the study are listed in Table 1. Two of the study's researchers, an internist and a cardiologist, reviewed the relevant medical records in order to determine whether one of the study's definitions of an adverse event was met. These reviewers were not informed of the study-group assignment of the patients. Medical events that occurred before discharge on the day of surgery were considered as related to the surgery. We did not include medical events after discharge because of difficulties in following up these patients.

\section{Sample size and statistical analysis}

A sample size of 1000 patients (500 per group) was planned. With an assumption of an adverse medical event rate of $9 \%$ in the routine-testing group, this sample size provided a $90 \%$ probability of detecting a difference as small as $7 \%$ in the selective-testing group. Results of these analyses were considered as statistically significant when the $P$ values were $<0.05$. We used Epi Info 2000 computer software (United States Centers for Disease Control and Prevention, Atlanta, Georgia, United States of America) for the statistical analyses. For categorical variables, chi-square (Yates) tests and Fisher's tests were used; for continu-

TABLE 1. Definitions of adverse medical events, cataract surgery study, Brazil, 2000-2001

\begin{tabular}{ll}
\hline \multicolumn{1}{c}{ Event } & \multicolumn{1}{c}{ Definition } \\
\hline Hypertension & $\begin{array}{l}\text { Increase in systolic pressure to }>179 \mathrm{~mm} \mathrm{Hg} \text { or in diastolic } \\
\text { pressure to }>109 \mathrm{~mm} \mathrm{Hg} \text { with new antihypertensive treatment, } \\
\text { or a change in treatment required } \\
\text { New or worsening disturbance of heart rhythm requiring new } \\
\text { treatment or a change in treatment }\end{array}$ \\
Arrhythmia & $\begin{array}{l}\text { New or more severe chest pain diagnosed as ischemia and } \\
\text { requiring treatment }\end{array}$ \\
Myocardial ischemia & $\begin{array}{l}\text { Abrupt onset of a focal neurologic deficit lasting }<24 \text { hours and } \\
\text { resulting from cerebrovascular ischemia } \\
\text { Wheezing or excessive coughing requiring a bronchodilator or } \\
\text { theophylline }\end{array}$ \\
Bronchospasm & Abrupt onset of a fear of death \\
\hline
\end{tabular}


TABLE 2. Characteristics of the patients, according to the group assignment, cataract surgery study, Brazil, 2000-2001

\begin{tabular}{|c|c|c|c|c|c|}
\hline \multirow[b]{3}{*}{ Characteristic } & \multicolumn{4}{|c|}{ Operations performed in group } & \multirow[b]{3}{*}{$P$} \\
\hline & \multicolumn{2}{|c|}{$\begin{array}{l}\text { Routine-testing }{ }^{\mathrm{a}} \\
\text { (502 patients) }\end{array}$} & \multicolumn{2}{|c|}{$\begin{array}{l}\text { Selective-testing } \\
\text { (503 patients) }\end{array}$} & \\
\hline & No. & $\%$ & No. & $\%$ & \\
\hline Sex: male & 275 & 54.8 & 264 & 52.5 & $0.466^{c}$ \\
\hline Risk class $^{d}$ & & & & & $0.839^{c}$ \\
\hline 1 & 70 & 13.9 & 76 & 15.1 & \\
\hline ॥ & 385 & 76.7 & 378 & 75.2 & \\
\hline III & 47 & 9.4 & 49 & 9.7 & \\
\hline
\end{tabular}

a Routine-testing group = cataract operation was preceded by routine testing.

${ }^{b}$ Selective-testing group = cataract operation was not preceded by routine testing.

c Significance according to chi-square test.

${ }^{d}$ Risk class according to the American Society of Anesthesiologists (ASA) classification system (18). ous variables, one-way analysis of variance (ANOVA) tables were used.

\section{RESULTS}

We enrolled 1025 patients scheduled to undergo cataract surgery between 10 February 2000 and 10 January 2001. The sample consisted of 512 patients assigned to the routine-testing group and 513 patients assigned to the selective-testing group. The two groups had similar proportions of operations that were canceled and not subsequently rescheduled, $2 \%$ in each group.

The two groups were well balanced in terms of age, with a mean age of 66.4 years (standard deviation $(\mathrm{SD})=$ 11.9 years) among the routine-testing group and of 66.7 years $(\mathrm{SD}=11.4$ years) among the selective-testing group (ANOVA $P=0.734$ ). The groups were also well balanced with respect to sex and risk of perioperative complications (Table 2) as well as coexisting illness (Table 3).

The cumulative rate of medical events was similar in the two groups, $9.6 \%$ in the routine-testing group and $9.7 \%$ in the selective-testing group $(P=$ 0.923). The types of medical events were similar in both groups (Table 4). Treatment for hypertension accounted for $85.4 \%$ of the events in the routinein the selective-testing group. testing group and $87.8 \%$ of the events

\section{DISCUSSION}

At the beginning of the 21st century, in terms of cataracts, worldwide there were 25 million blind individuals (visual acuity (VA) < 3/60) and 110 million visually impaired individuals $(\mathrm{VA}<6 / 60)(1,3,19)$. In an era when cost-benefit analysis is applied to all aspects of medical practice, including cataract surgery (20), unselective preoperative routine testing is no longer justified.

Forty years ago, physicians relied primarily on history-taking and physical examination to make preoperative medical assessments of cataract patients. Tests were ordered selectively to confirm clinical impressions. With advances in technology and the growing use of multiphasic batteries of laboratory tests, the goal became to formulate an early, presymptomatic diagnosis so as to optimize care. However, the use of these batteries of tests magnified two problems: the need to determine which tests, if any, should be required preoperatively, and the question of what should be done when test results are unexpectedly abnormal (21).

Ambulatory surgical procedures on an outpatient basis have proliferated in the last 20 years, as it became apparent that many procedures could be done in an ambulatory setting more cheaply and yet safely $(22,23)$. There
TABLE 3. Coexisting illness, according to the group assignment, cataract surgery study, Brazil, 2000-2001

\begin{tabular}{|c|c|c|c|c|}
\hline \multirow[b]{3}{*}{ Characteristic } & \multicolumn{4}{|c|}{ Operations performed in group } \\
\hline & \multicolumn{2}{|c|}{$\begin{array}{l}\text { Routine-testing } \\
\text { (502 patients) }\end{array}$} & \multicolumn{2}{|c|}{$\begin{array}{l}\text { Selective-testing } \\
\text { (503 patients) }\end{array}$} \\
\hline & No. & $\%$ & No. & $\%$ \\
\hline Hypertension & 247 & 49.2 & 241 & 47.9 \\
\hline Angina & 12 & 2.4 & 12 & 2.4 \\
\hline Myocardial infarction & 13 & 2.6 & 9 & 1.8 \\
\hline Arrhythmia & 24 & 4.8 & 21 & 4.2 \\
\hline Congestive heart failure & 4 & 0.8 & 6 & 1.2 \\
\hline Stroke & 3 & 0.6 & 5 & 1.0 \\
\hline Epilepsy & 4 & 0.8 & 6 & 1.2 \\
\hline Parkinson's disease & 2 & 0.4 & 1 & 0.2 \\
\hline Psychiatric disease & 7 & 1.4 & 6 & 1.2 \\
\hline \multicolumn{5}{|l|}{ Chronic obstructive } \\
\hline pulmonary disease & 29 & 5.8 & 25 & 5.0 \\
\hline Diabetes & 96 & 19.1 & 98 & 19.5 \\
\hline Anemia & 4 & 0.8 & 5 & 1.0 \\
\hline Bleeding disorders & 0 & 0.0 & 1 & 0.2 \\
\hline Renal disease & 9 & 1.8 & 10 & 2.0 \\
\hline Thyroid disease & 1 & 0.2 & 2 & 0.4 \\
\hline Liver disease & 1 & 0.2 & 0 & 0.0 \\
\hline Arthritis & 12 & 2.4 & 15 & 3.0 \\
\hline None of the above & 24 & 4.8 & 20 & 4.0 \\
\hline No disease & 10 & 2.0 & 20 & 4.0 \\
\hline
\end{tabular}

a Routine-testing group = cataract operation was preceded by routine testing

b Selective-testing group = cataract operation was not preceded by routine testing. 
TABLE 4. Types and numbers of adverse medical events, cataract surgery study, Brazil, 2000-2001

\begin{tabular}{|c|c|c|}
\hline Event & $\begin{array}{l}\text { Routine-testing group } \\
\text { (502 patients) }\end{array}$ & $\begin{array}{l}\text { Selective-testing group } \\
\text { (503 patients) }\end{array}$ \\
\hline \multicolumn{3}{|l|}{ Cardiovascular } \\
\hline Hypertension & 41 & 43 \\
\hline Arrhythmia & 1 & 0 \\
\hline Myocardial ischemia & 0 & 1 \\
\hline \multicolumn{3}{|l|}{ Cerebrovascular } \\
\hline Transient ischemic attack & 1 & 0 \\
\hline \multicolumn{3}{|l|}{ Pulmonary } \\
\hline Bronchospasm & 3 & 3 \\
\hline \multicolumn{3}{|l|}{ Psychiatric } \\
\hline Anxiety & 2 & 2 \\
\hline Total & 48 & 49 \\
\hline
\end{tabular}

${ }^{\text {a }}$ Routine-testing group $=$ cataract operation was preceded by routine testing.

${ }^{b}$ Selective-testing group $=$ cataract operation was not preceded by routine testing

are controversies regarding requests for preoperative tests for brief outpatient procedures. For patients undergoing cataract surgery there is a marked variation within and across physician specialties concerning the use of and rationale for medical tests, according to a survey conducted with ophthalmologists, anesthesiologists, and internists in the United States of America (24).

Too little knowledge can be a dangerous thing. Nonetheless, the apparent remedy-acquiring new informationmay create a more hazardous situation. In comparison to selectively ordered laboratory testing, screening-laboratory testing is a less comprehensive, less efficient, and less cost-effective tool, and it can lead to further unnecessary studies or treatments, costly delay in the performance of the procedures, and adverse medicolegal consequences if abnormal results are overlooked $(8,9,14,25)$.

The use of selective laboratory testing based on the medical history and the judgment of the surgeon in collaboration with capable consultants has been shown to be effective in recognizing subclinical problems in high-risk individuals and managing potentially complicating conditions $(8,9,13,26,27)$.

Our study had some limitations. It registered only clinically significant morbidities; for example, isolated atrial extrasystoles and other minor arrhythmias were not included. Another limitation was that a relatively succinct routine was adopted for patients assigned to the routine-testing group, ap- plying just three tests: 12-lead electrocardiogram, complete blood count, and measurements of serum glucose. Nevertheless, those are the most-requested preoperative tests for cataract surgery, and they were the standard routine at the academic medical center where this study was done $(23,24)$. Another limitation was that medical events related to the surgery were limited to just the period after the ambulatory procedure and before discharge. However, in one study (9), that period encompassed more than $75 \%$ of the cardiopulmonary events occurring within 7 days after the surgery. It is important to emphasize that the focus of our study was a relatively healthy population undergoing a low-risk procedure.

We believe medical assessment provides an important opportunity for physicians to reduce perioperative morbidity by optimizing preoperative status and planning perioperative management. However, the clinical usefulness of routine preoperative medical testing before cataract surgery is unproven. The results of this study suggest that routine medical testing before cataract surgery does not reduce the rate of complications during the perioperative period, and that it would be more efficient not to request routine preoperative tests unless they are indicated by patient history or physical examination. We think this is particularly true in developing countries, with their limited financial resources and their desire to clear the backlog of cataract cases.

\section{REFERENCES}

1. Apple DJ, Ram J, Foster A, Peng Q. Cataract: epidemiology and service delivery. Survey Ophthalmol 2000;45(suppl):32-44.

2. Foster A, Johnson G. Blindness in the developing world. Br J Ophthalmol 1993;77:398-399.

3. Wilson J. Clearing the cataract backlog. Br J Ophthalmol 1987;71:158-160.

4. Schwab L. Cataract. In: Schwab L. Eye care in developing nations. 3rd ed. San Francisco: The Foundation of the American Academy of Ophthalmology; 1999. pp. 21-52.

5. Linebarger EJ, Hardten DR, Shah GK, Lindstrom RL. Phacoemulsification and modern cataract surgery. Survey Ophthalmol 1999;44: 123-147.

6. Breslin P. Mortality in ophthalmic surgery. Int Ophthalmol Clin 1973;13:215-226.

7. Perez A, Planell J, Bacardaz C, Hounie A, Franci J, Brotons C, et al. Value of routine preoperative tests: a multicentre study in four general hospitals. Br J Anesth 1995;74: 250-256.

8. Wattsman TA, Davies, RS. The utility of preoperative laboratory testing in general surgery patients for outpatient procedures. Am Surg 1997;63:81-90.
9. Schein OD, Katz J, Bass EB, Tielsch JM, Lubomski LH, Feldman MA, et al. The value of routine preoperative medical testing before cataract surgery. N Engl J Med 2000;342(3): 168-175.

10. Bellan L. Preoperative testing for cataract surgery. Can J Ophthalmol 1994;29:111-114.

11. Roizen MF. Cost-effective preoperative laboratory testing. JAMA 1994;271:319-320.

12. Obstbaum SA. Variations in preoperative medical testing in healthy cataract surgery patients. Arch Ophthalmol 1993;113:12411242. 
13. Macpherson DS. Preoperative laboratory testing: should any tests be "routine" before surgery? Med Clin North Am 1993;77:289- 308

14. Lira RPC, Covolo GA, Monsanto AR, KaraJosé N, Arieta CEL. Influence of preoperative testing on cancellation of ambulatory cataract surgery in adults. Ann Ophthalmol. Forthcoming 2001.

15. Kaplan EB, Sheiner LB, Boeckmann AJ, Roizen MF, Beal SL, Cohen SN, et al. The usefulness of preoperative laboratory screening. JAMA 1985;253:3576-3581.

16. Macario A, Roizen MF, Thisted RA, Kim S, Orkin FK, Phelps C. Reassessment of preoperative laboratory testing has changed the testordering patterns of physicians. Surg Gynecol Obstet 1992;175:539-547.

17. Monteiro JV. Campanha nacional de cirurgias de catarata 2000. J Oftalmol Jota Zero 2000; $74: 4-5$
18. Owens WD, Felts JA, Spitznagel Jr EL. ASA physical status classifications: a study of consistency of ratings. Anesthesiology 1978;49: 239-243.

19. Kara-José N, Temporini ER. Cirurgia de catarata: o porquê dos excluídos. Rev Panam Salud Publica 1999;6:242-248.

20. Kara-José N, Delgado AMN, Arieta CEL. Exequibilidade da cirurgia de catarata em hospitalescola: em busca de um modelo econômico. Rev Assoc Med Bras 1994;40:186-188.

21. Roizen MF. More preoperative assessment by physicians and less by laboratory tests. N Engl J Med 2000;342:204-205.

22. Pollard JB, Zboray AL, Mazze RI. Economic benefits attributed to opening a preoperative evaluation clinic for outpatients. Anesth Analg 1996;83:407-410.

23. Arieta CEL, Kara-José N, Carvalho-Filho DM, Alves MR. Optimization of a cataract-patient care service in Campinas, Brazil. Ophthal Epid 1999;6:1-11.

24. Bass EB, Steinberg EP, Luthra R, Schein OD, Tielsch JM, Javitt JC, et al. Do ophthalmologists, anesthesiologists, and internists agree about preoperative testing in healthy patients undergoing cataract surgery? Arch Ophthalmol 1995;113:1248-1256.

25. Sisson JC, Schoomaker EB, Ross JC. Clinical decision analysis: the hazards of using additional data. JAMA 1976;236:1259-1263.

26. Litaker D. Preoperative screening. Med Clin North Am 1999;83:1565-1581.

27. McKibbin M. The pre-operative assessment and investigation of ophthalmic patients. Eye 1996;10:138-140.

Manuscript received 27 April 2001. Revised version accepted for publication on 27 June 2001.

RESUMEN Objetivos. El objetivo de este estudio consistió en determinar si la realización rutinaria de pruebas clínicas antes de la cirugía de cataratas reduce la tasa de complicaciones perioperatorias en adultos.

\section{¿Es necesario hacer pruebas clínicas rutinarias antes de la cirugía de cataratas?}

Métodos. El estudio se realizó en un centro médico universitario de Brasil entre el 10 de febrero de 2000 y el 10 de enero de 2001. Los pacientes con operaciones de cataratas programadas fueron asignados aleatoriamente a un grupo en el que las pruebas preoperatorias se realizaron de forma rutinaria (grupo R) o a un grupo en el que se realizaron de forma selectiva (grupo S). A los pacientes asignados al grupo $S$ solo se les solicitaron pruebas preoperatorias en caso de que presentaran un problema médico nuevo o agravado que justificara su realización. En el grupo R se practicaron tres pruebas preoperatorias de forma rutinaria: un electrocardiograma de 12 derivaciones, un hemograma completo y una determinación de la glucemia.

Resultados. De los 1025 pacientes estudiados, 512 fueron asignados al grupo R y 513 al grupo S. La proporción de intervenciones canceladas y no programadas nuevamente fue similar en ambos grupos: $2 \%$ en cada uno. La tasa acumulada de complicaciones médicas también fue similar en ambos grupos: 9,6\% en el grupo R y 9,7\% en el S ( $P=$ 0,923). Lo mismo ocurrió con los tipos de complicaciones médicas observadas.

Conclusiones. Los resultados de este estudio indican que la realización rutinaria de pruebas médicas antes de la cirugía de cataratas no reduce la tasa de complicaciones perioperatorias y que parece ser más eficiente no solicitar pruebas preoperatorias, a no ser que la historia clínica o la exploración física del paciente indiquen su realización. 